\title{
Uniwersalnie projektowanie a podnoszenie stopnia dostępności obiektów szpitalnych
}

\author{
Joanna Borowczyk \\ e-mail: joanna.borowczyk@p.lodz.pl
}

Zakład projektowania obiektów użyteczności publicznej, Instytut Architektury i Urbanistyki, Wydziat Budownictwa, Architektury i Inżynierii Środowiska, Politechnika tódzka

The Faculty of Civil Engineering, Architecture and Environmental Engineering,

Technical University of Łódź

\begin{abstract}
Streszczenie: Współczesny dyskurs architektoniczny z coraz większym zrozumieniem i zaangażowaniem wychodzi naprzeciw potrzebom i oczekiwaniom osób z rozmaitymi niepełnosprawnościami, a kreowaną przestrzeń analizuje się pod kątem możliwości przekroczenia progu występujących gdzie okiem sięgnąć uporczywych barier. Tymczasem w kształtowaniu pojęcia funkcjonalności obiektów, w tym budynków szpitalnych, coraz większą rolę odgrywać zaczyna idea uniwersalnego projektowania. Polska zobowiązana jest do wprowadzenia w życie zawartych w Konwencji Praw Osób Niepełnosprawnych (Rezolucja ONZ 61/06) reguł postępowania i zapewnienia wszystkim możliwie najwyższego standardu i dostępu do usług zdrowotnych. Wymaga to od nas odpowiedzi na pytanie: jak aranżować budynki i usługi medyczne, aby możliwa stała się realizacja zasad określonych w art. 25 Konwencji. Kompleksowa restrukturyzacja w ramach zintegrowanych metod uwzględniających wszystkich potencjalnych użytkowników szpitali, może tworzyć ważny element działań na rzecz odnowy i wytyczenia dalszych kierunków rozwoju budownictwa służby zdrowia. Obiekty medyczne stanowią w omawianym kontekście problem newralgiczny, ponieważ ich użytkownikami będą bez wątpienia osoby z obniżoną funkcjonalnością, wpływającą na zmniejszenie sprawności fizycznej i sensorycznej. Wynika z tego, że budynek służby zdrowia należy planować uwzględniając wszelkie rozwiązania gwarantujące pacjentom i ich rodzinom poczucie godności, a także warto promować narzędzia projektowe, które zachęcą do samodzielnego korzystania z przestrzeni bez szkodliwego wrażenia niepokoju czy zagrożenia.
\end{abstract}

Słowa kluczowe: architektura szpitali, dostępność, projektowanie uniwersalne

\section{Wprowadzenie}

Współczesny dyskurs architektoniczny z coraz większym zrozumieniem i zaangażowaniem wychodzi naprzeciw potrzebom i oczekiwaniom osób z rozmaitymi niepełnosprawnościami, a kreowaną przestrzeń analizuje się pod kątem jej dostępności oraz możliwości przekroczenia progu występujących gdzie okiem sięgnąć uporczywych barier. Tymczasem w kształtowaniu pojęcia funkcjonalności obiektów, w tym budynków szpitalnych, coraz większą rolę odgrywać zaczyna idea uniwersalnego projektowania. Respektowanie jej zasad przynieść ma z założenia korzyści całemu społeczeństwu, w tym także tym jego członkom, którzy do tej pory pozostawali dyskryminowani ze względu na istniejące w przestrzeni fizyczne przeszkody. Celem nadrobienia dotychczasowych zaległości w zakresie koordynacji działań, polegających na zwiększaniu dostępności przestrzeni, produktów i usług, Unia Europejska wprowadza dyrektywy służące zapewnieniu osobom z niepełnosprawnościami instrumentów realizacji ich praw. Polska zobowiązana jest do wprowadzenia w życie zawartych w Konwencji Praw Osób Niepełnosprawnych (Rezolucja ONZ 61/06) reguł postępowania i zapewnienia wszystkim możliwie najwyższego standardu i dostępu do usług zdrowotnych.

Wymaga to od nas odpowiedzi na trudne pytanie: jak aranżować budynki i usługi medyczne, aby możliwe stało się urzeczywistnienie postulatów określonych w art. 25 Konwencji. Bariery dostępności są bowiem nieodłącznym elementem polskich szpitali, wznoszonych zarówno przed wybuchem II wojny światowej, jak 
i tych późniejszych, projektowanych na podstawie uśrednianych danych antropometrycznych „człowieka socjalistycznego". Kompleksowa restrukturyzacja w ramach zintegrowanych metod uwzględniających wszystkich potencjalnych użytkowników szpitali, może stanowić ważny element działań na rzecz odnowy i wytyczenia dalszych kierunków przemian budownictwa służby zdrowia. Należy założyć, że omawiana modernizacja będzie następowała etapowo, ponieważ radykalne przekształcenie lub zastąpienie istniejącej zabudowy oznacza koszty w skali niemożliwej do sfinansowania w przewidywalnej przyszłości. Tym pilniejsza staje się racjonalizacja działań organów administracyjnych i planistycznych, szkół wyższych, organizacji naukowych oraz projektantów dokonywana poprzez wspólne i klarowne określenie priorytetów rozwoju szpitali, jako budynków przyjaznych i dostępnych dla wszystkich.

Obiekty medyczne stanowią w omawianym kontekście problem newralgiczny, ponieważ ich użytkownikami będą bez wątpienia osoby z obniżoną funkcjonalnością, wpływającą na zmniejszenie sprawności fizycznej i sensorycznej, a wynikającą z długotrwałego stanu występowania pewnych ograniczeń lub przejściowych chorób somatycznych i osłabienia. A zatem budynek służby zdrowia należy planować uwzględniając wszelkie rozwiązania gwarantujące pacjentom i ich rodzinom poczucie godności i niezależności, a także warto promować narzędzia projektowe, które zachęcą do samodzielnego korzystania z przestrzeni bez uczucia niepokoju czy zagrożenia. Wychodząc bowiem od twierdzenia, że niemożność pełnego funkcjonowania człowieka niekoniecznie wynika z ograniczeń w prawidłowym działaniu jego organizmu i powstawać może na skutek barier występujących po stronie otoczenia, autorka artykułu zadaje następujące pytania:

- jakie są zasady uniwersalnego projektowania obiektu szpitalnego?

- czy każdy budynek służby zdrowia może być uniwersalnie zaprojektowany?

- jakie działania należy podjąć i jakie koszty ponieść, aby szpital stał się miejscem dostępnym i przyjaznym dla pacjentów, ich rodzin i personelu medycznego?

- jaką rolę w planowaniu przyszłości użytkowników obiektów medycznych spełnić mają tzw. standardy dostępności, takie jak Standard Dostępności dla Łodzi, opracowywany przez łódzkie organizacje i stowarzyszenia skupiające osoby z rozmaitymi niepełnosprawnościami?

\section{Uniwersalne projektowanie szpitala w dyskursie teoretycznym}

XX wiek był dla historii architektury czasem pod każdym względem przełomowym, bo choć twórców przestrzeni od setek lat interesował wpływ środowiska fizycznego na człowieka, to właśnie wówczas wprowadzono do dyskursu architektonicznego pojęcie "użytkownika" [1], a pod koniec stulecia także szeroko rozpowszechniony dziś termin: „projektowanie uniwersalne” [2]. Koncepcja projektowania uniwersalnego rodziła się w erze rozwoju ruchów na rzecz praw cywilnych w Stanach Zjednoczonych. Pierwsze przepisy z omawianego zakresu wprowadzono na początku lat 90. w USA przez powołanie ustawy pn. The Americans with Disabilities Act (ADA). Wynikające z niej akty wykonawcze oparte zostały na zasadach prawa antydyskryminacyjnego [3].

W dniu dzisiejszym to zapisy Konwencji Praw Osób Niepełnosprawnych, przyjętej przez Zgromadzenie Ogólne Narodów Zjednoczonych 13 grudnia 2006 roku, dostarczają nam ram ochrony praw osób z niepełnosprawnościami, negując dyskryminację ze względu na obniżoną sprawność intelektualną i ograniczenia funkcjonalne w zakresie komunikowania się, percepcji czy mobilności. W rozumieniu dokumentu, którego ratyfikacja przez Polskę miała miejsce 6 września 2012 roku, wszelkie formy różnicowania i wykluczania, w tym zaniechanie racjonalnego dostosowania środowiska do szczególnych potrzeb osób z niepełnosprawnościami, stanowią wykroczenie przeciwko godności i wartości człowieka. Omawiany dokument wnosi również definicję „racjonalnego dostosowania", oznaczającego "konieczne i stosowne modyfikacje i adaptacje, niepociągające za sobą nieproporcjonalnych i niepotrzebnych utrudnień, które to modyfikacje i adaptacje są niezbędne w określonych przypadkach dla zapewnienia osobom niepełnosprawnym możliwości egzekwowania i korzystania z wszystkich praw człowieka i fundamentalnych swobód" [4]. Polska zobowiązana jest do wprowadzenia w życie zawartych w Konwencji standardów postępowania, w celu zapewnienia osobom z niepełnosprawnościami realizacji ich praw, m. in. poprzez działania polegające na rozpoznawaniu i usuwaniu przeszkód i barier na drodze do dostępności budynków, dróg, środków transportu oraz innych obiektów, w tym ośrodków medycznych i miejsc pracy.

Komisja Europejska rozwija wymogi stosowania zasad dostępności i „projektowania dla wszystkich" w obszarze zamówień publicznych [5], a projektowanie uniwersalne rozumiane jest jako jedno ze strategicznych 
narzędzi realizacji zasady równości i zrównoważonego rozwoju, głównie w jego wymiarze społecznym. A zatem produkty i obiekty stworzone zgodnie ze standardami projektowania uniwersalnego nie wymagają adaptowania ani wprowadzania dodatkowych rozwiązań dla osób z grup wykluczanych, czego w teorii architektury flagowym już przykładem jest wykonanie jednego, wspólnego dla wszystkich użytkowników wejścia do obiektu i rezygnacja z segregacji przestrzennej, wynikającej z faktu, że osoby z niepełnosprawnością ruchową mogą dostać się do budynku jedynie poprzez boczne i specjalistycznie przystosowane wejście. Idea uniwersalnego projektowania oparta jest bowiem na założeniu, że opracowywane koncepcje nie powinny być stygmatyzujące, a zatem poszukiwać należy rozwiązań, których wyraz formalny i funkcjonalny nie wskazuje na to, że mają one charakter specjalistycznych środków projektowych, kierowanych wyłącznie do grupy osób ze specjalnymi potrzebami, bądź obniżoną sprawnością.

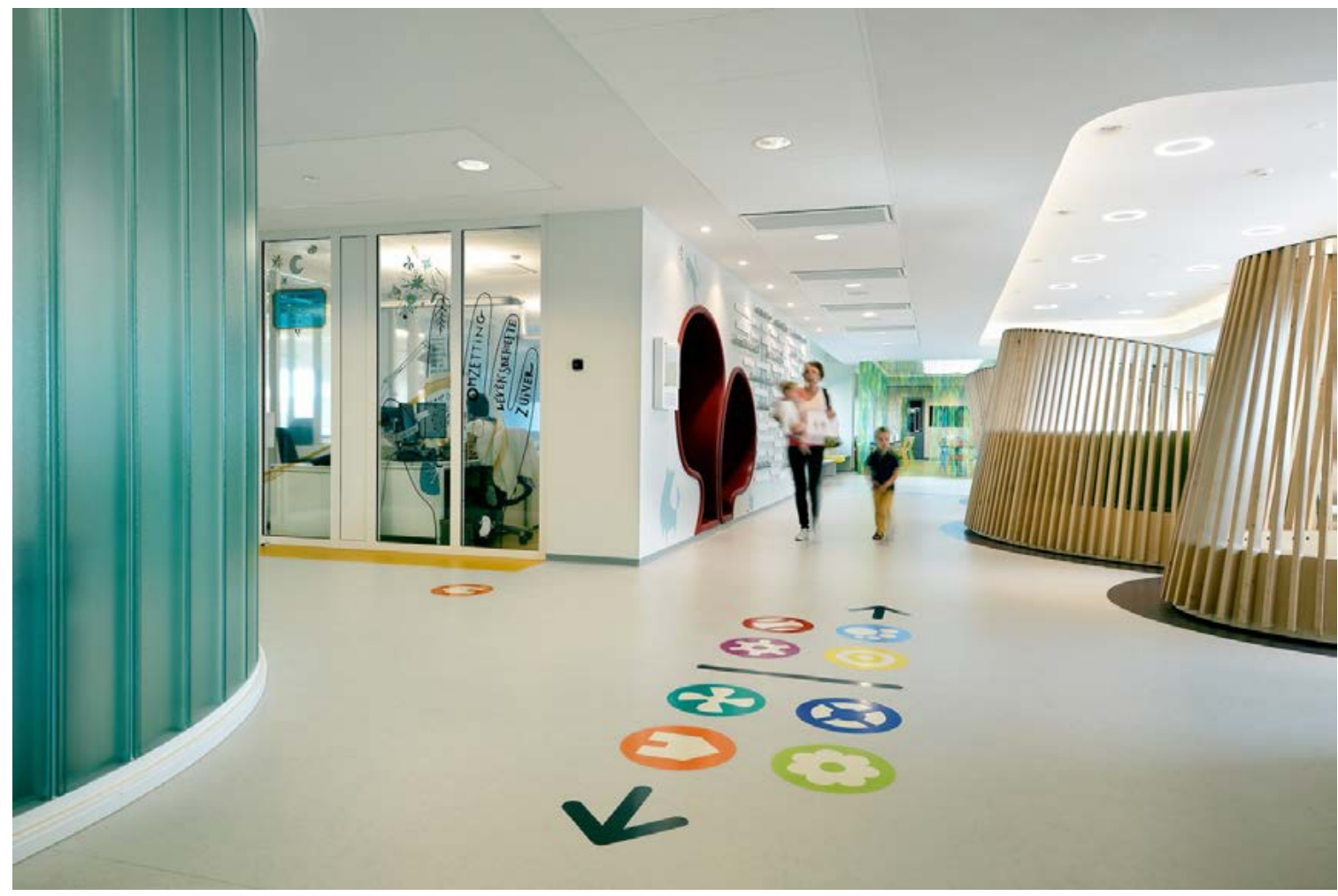

Ryc. 1. Szpital pediatryczny Emma Kinderkrankenhaus - Academisch Medisch Centrum (AMC) w Amsterdamie. Przykład nowoczesnego systemu komunikacji szpitala wzbogaconego o program informacji przestrzennej, uwzględniającej m.in. zróżnicowanie grup wiekowych pacjentów.

Źródło: (http://www.gebouwvanhetjaar.nl/entry/emma-kinderziekenhuis-amc/, dostęp : 03.12.2016).

Coraz szerzej rozpowszechniana idea nie jest minimalistyczną postawą, polegającą na zagwarantowaniu dostępu w skromnej, wymaganej obowiązującymi przepisami formie. Zgodnie z siedmioma zasadami projektowania uniwersalnego, opracowanymi na Uniwersytecie Stanowym Karoliny Północnej (ang. North Carolina State University) w 1997 roku przez grupę projektantów i naukowców pod kierunkiem amerykańskiego architekta z niepełnosprawnością Ronalda Mace 'a, dąży się do zapewnienia wszystkim tego samego standardu użytkowania przestrzeni i usług. Promowaną ideę równości w korzystaniu dla osób o różnej sprawności (ang. Equitable Use), uznać dziś można za absolutnie obowiązujący atrybut przestrzeni szpitalnej w strefach dostępnych dla pacjentów i odwiedzających. Przestrzeganie tej zasady pozwoli bowiem unikać rozwiązań, które pogłębiałyby podziały i stygmatyzację użytkowników, naruszały ich prywatność, bezpieczeństwo i poczucie pewności. W przypadku obiektów służby zdrowia szczególnie użyteczna okazać się może także druga zasada omawianej strategii, odnosząca się do elastyczności proponowanego rozwiązania w użytkowaniu (ang. Flexibility in Use). Oznacza ona że projekt budynku uwzględnia indywidualne preferencje użytkowników (w zależności od 
możliwości z zakresu mobilności i percepcji), pozwala na wybór metody użytkowania i jest zaplanowany w sposób gwarantujący dokładność i precyzję oraz różne tempo korzystania z proponowanych rozwiązań.

Omówienie charakterystyki osób poddawanych leczeniu szpitalnemu nie jest możliwe, ponieważ pod pojęciem tym kryje się wiele stanów psychofizycznych. Problemy zdrowotne i pielęgnacyjne pacjentów, deficyty samodzielności, wrażenie osamotnienia i lęku, utrata poczucia bezpieczeństwa fizycznego i psychicznego oraz doświadczenie zagubienia, zwłaszcza w nowych przestrzeniach, rodzą szereg trudności, wywołujących konieczność specyficznego podejścia do projektowania budynków możliwie intuicyjnych w użytkowaniu, pozbawionych zbędnych zawiłości oraz uwzględniających stan wiedzy i umiejętności pacjenta (ang. Simple and Intuitive Use). Z tych samych przyczyn coraz większą uwagę poświęca się kreowaniu czytelnych systemów informacji w obiektach (ang. Perceptible Information), których elementami są m. in. informacja głosowa i dotykowa, kolorowe piktogramy oraz możliwości wykorzystania indywidualnych urządzeń będących w dyspozycji osób z ograniczeniami sensorycznymi [Rys. 1].

Choć trudno znaleźć prostą receptę na "dobry” projekt szpitala, zwłaszcza, że placówki różnią się od siebie lokalizacją, wielkością mierzoną liczbą łóżek pacjentów czy specjalizacją, każda koncepcja modernizacji bądź też budowy nowego obiektu wymaga wypracowania metod redukcji przewidywanych i przypadkowych zagrożeń oraz możliwości popełnienia błędów (ang. Tolerance for Error), związanych z użytkowaniem budynku, co realizuje się poprzez właściwe ostrzeżenia, lokalizację zapewniającą dostępność rozwiązań oraz ograniczanie czynności wywołujących znużenie fizyczne i psychiczne. Z powszechnie zrozumiałych powodów stosuje się środki i narzędzia pozwalające zachować pacjentowi właściwą dla niego pozycję ciała, niewymagające nadmiernego wysiłku oraz niepowodujące konieczności ciągłego powtarzania czynności obligujących do użycia siły (ang. Low Physical Effort) oraz zapewnia się w budynku przestrzeń właściwą do wykonania danego działania przez wszystkich użytkowników, w tym osoby z ograniczeniami mobilności i percepcji (ang. ang. Size and Space for Approach and User). Wymagania dostępności nie dotyczą jedynie wielkości przestrzeni i obejmują konieczność przystosowania obiektu do szeregu kryteriów, w tym: warunków ergonomicznych dla pacjentów leżących czy pola widzenia uwzględniającego szeroki zakres wysokości oczu przyszłych użytkowników. Zapewnienie przestrzeni koniecznej dla korzystania z indywidualnych urządzeń będących w dyspozycji osób z ograniczeniami, asysty opiekunów oraz innych środków pomocy osobistej, jest oczywistym warunkiem prawidłowego funkcjonowania obiektu służby medycznej.

$Z$ dużym prawdopodobieństwem największe problemy w przełożeniu na szeroko rozumianą praktykę architektoniczną rodzić może ostatnia i uzupełniająca zasada projektowania uniwersalnego, zdefiniowana przez Kondrada Kaletscha jako „Percepcja Równości” (ang. Perception of Equality). „Odnosi się to do sytuacji, gdy indywidualna ocena rozwiązania może wpływać na postrzeganie siebie, jak również postrzeganie przez innych naszych różnic fizycznych czy niepełnosprawności jako cech dyskryminujących lub niewspółmiernie wyróżniających" [5]. Podkreślić należy, że już sama pozycja społeczna pacjenta w obowiązującym systemie służby zdrowia bywa u chorych czynnikiem decydującym o poczuciu dyskryminacji. Możliwe jednak jest także to, że unikanie sytuacji, w której korzystający z budynku czuje się stygmatyzowany, okaże się zadaniem łatwiejszym w realizacji w przypadku budynku szpitalnego, z uwagi na specyfikę funkcji, w tym przewidywane ograniczenia mobilności i percepcji większości użytkowników [6].

Podczas gdy eksperci międzynarodowych organizacji takich jak Global Alliance on Accessible Technologies and Environments dowodzą, że "rozwój zrównoważony można zaobserwować tylko tam, gdzie kody i standardy dotyczące budownictwa są oparte właśnie na zasadach projektowania uniwersalnego" [2], spełnienie wszystkich omówionych warunków nie zawsze jest korzystne i nie zawsze jest prawdopodobne w realizacji w krajowym systemie prawnym i przy stanie jakości istniejących budynków. Stąd wielu profesjonalistów proponuje stosować tymczasowe substytucyjne rozwiązania udostępniające, opisywane w Polsce w tzw. standardach dostępności, dokumentach zawierających kryteria w znacznej mierze wynikające z filozofii "projektowania dla wszystkich".

\section{Rola standardów dostępności}

Wdrażanie zasad projektowania uniwersalnego do praktyki projektowej jest z natury dalece bardziej zawiłe niż instynktowne zrozumienie samej koncepcji. W warstwie teoretycznej omawiana idea podważa sens wielu działań, polegających na wtórnym podnoszeniu dostępności obiektów medycznych, natomiast doświadczenia 
z modernizacji istniejących szpitali wyraźnie wskazują, że teoretycznie słuszne poglądy sprowadzone są do mniej lub bardziej prawidłowego przestrzegania zaledwie kilku ogólnych wytycznych zawartych w obowiązujących aktach prawnych. Zarówno ustawa Prawo Budowlane, jak i Rozporządzenie Ministra Infrastruktury z dnia 12 kwietnia 2002 r. w sprawie warunków technicznych, jakim powinny odpowiadać budynki i ich usytuowanie (Dz. U. z 2002 r. Nr 75, poz. 690 ze zm.), nie precyzują w wystarczającym stopniu wymagań zapewnienia pełnej przystępności obiektów dla osób z różnym zakresem niepełnosprawności, a dodatkową trudnością na drodze do likwidacji istniejących barier jest aktualny brak możliwości skutecznego egzekwowania wymogów dostępności, ponieważ konieczność dostosowania dotyczy jedynie obiektów nowych i modernizowanych po wejściu w życie ustawy Prawo budowlane (po 1 stycznia 1995 r.). Jako, że szczegółowych wytycznych postępowania nie określa krajowe prawodawstwo, przydatne okazuje się sporządzanie „standardów dostępności" - aktów prawa miejscowego zgodnych z obowiązującymi normami i je uzupełniających. Standardy dostępności rozumiane są jako zbiory wytycznych tzw. dobrej praktyki, a ich zastosowanie zapewnić może wielu potencjalnym użytkownikom odpowiedni poziom dostępności przestrzeni miejskich i części obiektów użyteczności publicznej, przy jednoczesnym spełnieniu warunków wynikających z obowiązujących ustaw, w tym przepisów budowlanych.

Obecnie zakładamy a priori, że od budynku zaprojektowanego zgodnie z zasadami projektowania uniwersalnego oczekiwać możemy „pełnej dostępności” we współczesnym rozumieniu, natomiast kwalifikacja obiektu jako "dostępnego" nie gwarantuje, że został on zaplanowany zgodnie z rozpatrywaną szczegółowo w poprzednim punkcie artykułu ideą. Gdy ponad ćwierć wieku temu rodziła się koncepcja projektowania uniwersalnego, jej twórcy polegali na przeświadczeniu o patogeniczności stosowania uśrednionych parametrów dotyczących potencjalnego użytkownika w kreowaniu przestrzeni i usług do niego adresowanych [2]. Tymczasem spodziewane urzeczywistnienie omawianej koncepcji w praktyce okazuje się być mocno oparte na metodzie tworzenia i rozwijania zasobu informacji na temat wybranych normatywnych możliwości umysłu i ciała człowieka. Choć całkowicie odrzuca się tradycyjne, i słusznie uznawane dziś za naganne, podziały na to co naturalne i normalne oraz to co nieprawidłowe czy wręcz "kalekie", analizy dostępności obiektów dokonuje się często w referencji do "użytkownika ekstremalnego", czyli takiego który potencjalnie może mieć największe trudności w skorzystaniu z budynku, chodnika, tramwaju czy strony internetowej [7]. Jest to na ogół uzasadnione, bo gdy projektując toaletę przy pokoju chorego przyjmiemy jako punkt wyjścia potrzeby osoby poruszającej się na wózku, to $w$ efekcie otrzymamy pomieszczenie, z którego skorzysta większość pacjentów. Jeśli w obiekcie szpitalnym rejestrację i punkt informacji zaplanujemy blisko wejścia i w odpowiedni sposób ją oznakujemy (aby ułatwić dostęp osobom niewidomym i niesłyszącym), to z rozwiązania tego pożytek będzie miał każdy z nas, bo poszukiwanie rejestracji na 5 minut przed wizytą u lekarza jest trudne dla każdego.

Projekty realizowane zgodnie z opracowywanymi aktualnie w całej Polsce standardami mają zatem szansę być tworzone nie tylko z myślą o ograniczonej grupie adresatów, np. o osobach z niepełnosprawnością ruchową, co stanowiło do tej pory nazbyt częstą praktykę i wynikało w dużej mierze zapisów prawnych, w tym artykułu 5 ustawy Prawo budowlane. Standardy nie stanowią bowiem zestawu rozwiązań służących osiągnieciu minimalnego poziomu dostępności. Ich szczegółowość, w przeciwieństwie do kilku punktów z wytycznych ustawy, daje nadzieję na sprostanie potrzebom wielu ludzi doświadczających w istniejących obiektach medycznych przestrzennego i społecznego wykluczenia.

\section{Droga ku dostępności}

Prawidłowe zastosowanie standardów dostępności i, w miarę możliwości, realizacja koncepcji projektowania uniwersalnego, wymaga podjęcia wielu przemyślanych decyzji, a w przypadku szpitali istniejących dokonania niezbędnych korekt, w celu zapewnienia osobom z niepełnosprawnościami warunków korzystania z budynków na zasadach najbliższych regułom oferowanym reszcie społeczeństwa. Zalecanym przez krajowych i zagranicznych ekspertów narzędziem eliminowania bezprawnej dyskryminacji i wiktymizacji w obiektach sektora publicznego jest sporządzanie na etapach projektowania budynków i ich użytkowania tzw. strategii dostępności [6]. Strategia stanowi studium, które umożliwia określenie jakie są potrzeby użytkowników i w jaki sposób je zrealizować, tworząc budynek przyjazny, nie narażając zarazem korzystnych fragmentów substancji obiektu, co może mieć miejsce w przypadku zabytku czy wyspecjalizowanego szpitala o skomplikowanym i precyzyjnie 
zaplanowanym układzie przestrzennym. Poprawnie i szczegółowo skonstruowana strategia dostępności dostarczać powinna odpowiedzi na pytania [Rys. 2, 3]:

- co należy usprawnić: sam budynek, sposób zarządzania budynkiem, czy jedno i drugie?

- jakie rozwiązania udostępniające należy wprowadzić i jakie są nasze powinności z zakresu ochrony obiektów cennych pod względem historycznym i kulturowym?

- kto będzie odpowiedzialny za zbilansowanie powyżej wymienionych priorytetów i obowiązków?

- ile będzie trwało dostosowanie obiektu i jak dużo będzie kosztowało?

Ponieważ żadna z obowiązujących ustaw nie precyzuje, w jaki sposób zagwarantować można pełnią dostępność budynku, indywidualnego rozważenia wymaga decyzja: czy zmiany wymaga struktura fizyczna obiektu, czy można tej zmiany uniknąć aranżując przestrzeń w alternatywny sposób. Nie zawsze bowiem konieczne okazuje się usuwanie fizycznej przeszkody i w niektórych przypadkach reorganizacja w wykorzystaniu przestrzeni i systemie zarządzania szpitalem może okazać się wystarczająca.

Kolejnym krokiem jest przeprowadzenie audytu dostępności, który pozwoli ocenić i udokumentować bariery istniejące w budynku opieki zdrowotnej i w jego otoczeniu. Autorzy audytu rozważyć muszą szerokie spektrum potencjalnych niepełnosprawności i przejściowych stanów występowania ograniczeń w funkcjonowaniu organizmu pacjentów i pozostałych użytkowników szpitala. Podstawową zasadą prawidłowo przeprowadzonego audytu jest wykonywanie poszczególnych czynności we właściwej, logicznej kolejności, od przybycia do budynku, poprzez wejście, weryfikację dostępności poszczególnych usług i funkcji, aż po wyjście, w tym także możliwość opuszczenia budynku w razie nagłego wypadku czy pożaru. Celem prowadzonej analizy jest porównanie obecnej sytuacji z możliwymi konsekwencjami zmian oraz identyfikacja wszelkich potencjalnych barier dostępności, za wyjątkiem przestrzeni o parametrach ściśle określonych przez technologię leczenia.

Po dokonaniu audytu dostępności szpitala oraz identyfikacji uwarunkowań projektowych, wykonalne staje się opracowanie koncepcji dostępności, obejmującej m.in. rozważenie praktycznych rozwiązań dostosowanych do potrzeb osób z różnymi ograniczeniami, analizę pogodzenia priorytetów konserwatorskich z priorytetami dostępności, optymalizację proponowanych metod i narzędzi projektowych. Na tym etapie zasięga się opinii potencjalnych użytkowników z niepełnosprawnościami oraz prowadzi się konsultacje ze specjalistami z różnych dziedzin, a w przypadku obiektów o historycznym rodowodzie, także z konserwatorem zabytków. Ostateczny plan dostępności pomoże rozważyć krótko- i długoterminowe cele, skalkulować ramy czasowe realizacji, wskazać wymagane prawem uzgodnienia i zezwolenia. W przypadku szpitali, funkcji narzucających konieczność prowadzenia prac modernizacyjnych w czasie nieprzerwanej działalności obiektu, planowane działania wymagają rozłożenia w czasie, a niekiedy również umożliwienia okresowego świadczenia usług w sposób alternatywny.

W przeciwieństwie do procesu projektowania nowego szpitala, procedura planowania zwiększenia dotychczasowej dostępności istniejącej placówki, jest często oparta na poszukiwaniu sposobów pokonywania fizycznych przeszkód występujących w przestrzeni obiektu. Potencjalne przeszkody można podzielić na dwie podstawowe kategorie: zewnętrzne elementy obiektu i jego otoczenia (cechy krajobrazu i fragmenty zagospodarowania terenu, takie jak: wysokie krawężniki, nierówne płyty chodnikowe, bariery przy wejściach do budynku i na trasach ewakuacyjnych) oraz elementy fizycznej struktury budynku, wynikające z jego szczególnej funkcji, konstrukcji oraz formy, w tym detalu architektonicznego (np. cokoły i bazy kolumn, elementy ślusarki i stolarki drzwiowej, stałe i ruchome elementy wyposażenia). Jeśli usunięcie bariery stwarza zagrożenie dla utrzymania dotychczasowej, sprawnej funkcji budynku szpitalnego, lub istnieje obawa zatracenia oryginalnego charakteru obiektu, racjonalnym dostosowaniem może okazać się rozważne ominięcie przeszkody. W publikacjach powołanej przez rząd Wielkiej Brytanii instytucji pn. Historic Buildings and Monuments Commission for England, wymienia się cztery podstawowe strategie przezwyciężania barier fizycznych, występujących w istniejących obiektach: usunięcie przeszkody, modyfikacja przeszkody, opracowanie racjonalnej metody omijania przeszkody oraz, w przypadku gdy żadna z wcześniej wymienionych opcji nie jest możliwa, świadczenie usługi w sposób alternatywny [8]. Rzeczone wydawnictwa nie determinują nadrzędności któregokolwiek wariantu postępowania, ale zasady dobrej praktyki wskazują na pierwszeństwo dla usuwania lub zmiany cechy fizycznej tworzącej barierę, co wynika bezpośrednio z zapisów cytowanej w artykule w Konwencji Praw Osób Niepełnosprawnych oraz coraz szerzej uznawanych zasad uniwersalnego projektowania. 

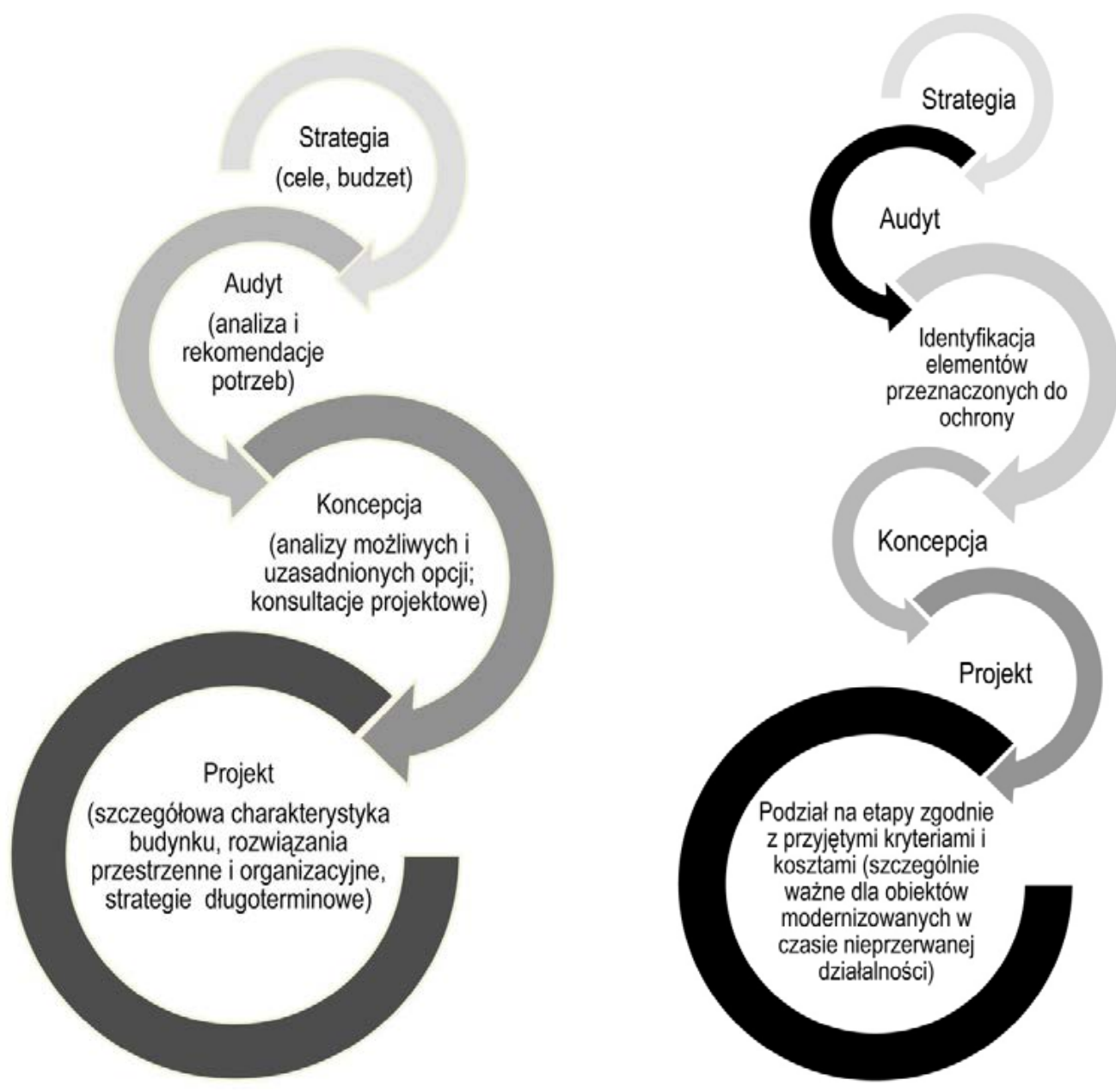

Ryc. 2. Uproszczony schemat procesu planowania dostępności nowoprojektowanego budynku szpitalnego oraz schemat procedury planowania dostępności szpitala modernizowanego.

Oprac. autorka na podstawie: Easy Access to Historic Buildings, Historic England, 2015, (https://www.visitengland.com/sites/ default/files/historic_england_easy_access_to_historic_buildings_2015.pdf, dostęp : 03.06.2015).

Tymczasem doświadczenia projektowe z zakresu modernizacji polskich szpitali dowodzą, że w strukturze większości istniejących obiektów, zarówno zabytkowych jak i tych nieobjętych ochroną konserwatorską, występują liczne stwarzające utrudniania fragmenty, których eliminacja nie jest możliwa ze względu na funkcję budynku, bądź jego wartość historyczną. Nagminnie napotykamy także takie bariery, których przebudowa lub likwidacja nie spełnia warunku racjonalnego dostosowania. Do elementów takich należą $\mathrm{m}$. in. niespełniające wymagań obowiązującego prawa klatki schodowe czy uformowane w procesie historycznym wejścia do budynków, w których stopnie są jedyną drogą pokonywania różnicy wysokości pomiędzy poziomem parteru a poziomem terenu. W przypadkach gdy decyzja o usunięciu tego typu składowych szpitala nie jest trafnym wyborem (ze względu na historyczną tożsamość obiektu, wrażliwą konstrukcję, oszczędności finansowe lub możliwości dezintegracji formy i funkcji stosunkowo sprawnego budynku), rozważyć można zmiany polegające na uzupełnianiu struktury, np. o dodatkową klatkę schodową, windę czy pochylnię przy istniejącym wejściu do obiektu. Choć nie jest to równoznaczne z zasadami projektowania uniwersalnego, nie można przy planowaniu długoterminowej przyszłości placówki wykluczać możliwości stosowania elementów tymczasowych, odpowiadających aktualnym potrzebom jej użytkowników. W przypadku szpitali objętych ochroną konserwatorską, rozwiązania takie mogą okazać się najbardziej uzasadnione, ponieważ skutecznie podniosą dostępność budynku, nie powodując zarazem trwałych i nieodwracalnych zmian w oryginalnej tkance architektonicznej. Kolejną 
wartą rozważenia możliwością jest dokonanie koniecznego retuszu dotychczasowej funkcji, przy czym zazwyczaj korekty te związane są z minimalnym wpływem na istniejącą strukturę budynku i polegają na drobnych zmianach w przeznaczeniu i układzie pomieszczeń. Tego typu metody, wykraczające poza standardowe rozwiązania, obejmować mogą łagodną redukcję bariery, która zastępuje jej definitywną eliminację. Charakter funkcji medycznej wyklucza natomiast przeważnie możliwość świadczenia usług w sposób alternatywny, polegający między innymi na przekazywaniu informacji za pomocą druku, drogą elektroniczną, bądź przez zastosowanie środków audiowizualnych.

Jak dowodzą przeprowadzone analizy, do dyspozycji mamy szeroki wachlarz narzędzi przezwyciężania istniejących barier, jednak wydaje się, że ostateczny wybór metody powinien być dokonywany w konsultacji z obecnymi i przyszłymi użytkownikami szpitala w celu stwierdzenia, czy akceptują oni proponowane metody świadczenia usługi i czy nie interpretują ich jako dyskryminujące. Rodzaj funkcji i sposób jej realizowania wewnątrz budynku są ważnymi parametrami decydującymi o stosownym poziomie dostępności i stopniu dokonywanych zmian. Także możliwości organizacyjne oraz zasoby finansowe placówki służby zdrowia są kluczowym czynnikiem rozstrzygającym o tym, czy potencjalne korekty uznać można za racjonalne i uzasadnione.

Na idei projektowania uniwersalnego oraz koncepcji budynku dostępnego ciąży wiele szkodliwych mitów, takich jak ten, że pełna dostępność obiektów użyteczności publicznej zagwarantowana jest obowiązującymi normami prawnymi oraz, że rozwiązania służące podnoszeniu stopnia dostępności są nieatrakcyjne z punktu widzenia estetyki. Prowadzone w Stanach Zjednoczonych analizy dowodzą, że nieprawdą jest również założenie, że koszty budowy nowego obiektu, zaprojektowanego zgodnie z zasadami dostępności, przekraczają koszty budowy obiektu nieprzystosowanego do potrzeb osób z ograniczeniami mobilności i percepcji. Wyniki badań publikowanych przez Uniwersytet Stanowy w Nowym Yorku (ang. The State University of New York, School of Architecture and Planning University at Buffalo) wykazują, że koszty realizacji nowego budynku użyteczności publicznej, planowanego już na wczesnym etapie projektowania jako obiektu dostępnego, przewyższyły całkowite nakłady na inwestycję nieprzystosowaną do potrzeb osób z niepełnosprawnościami o mniej niż 1\% (badanie: The Cost of Accessible Housing, US Department of Housing and Urban Development) [9].

Wypada podkreślić, że będące przedmiotem analiz wydatki mogą się znacząco różnić w zależności od lokalnych uwarunkowań, specjalizacji i standardu realizowanego szpitala oraz indywidualnych decyzji projektowych. Oszacowanie kosztów wymaga dokładnych badań studialnych wielu obiektów, zarówno w kontekście założeń projektowych, jak i warunków ich późniejszego użytkowania. Ponoszone nakłady finansowe okazują się jeszcze trudniejsze do zweryfikowania w przypadku obiektów istniejących, wtórnie przystosowywanych do potrzeb przestrzennych osób z niepełnosprawnościami. Aby ograniczyć potencjalne koszty adaptacji nowo realizowanej infrastruktury w przyszłości, należy zatem rzetelnie przeanalizować i uwzględnić zasady warunkujące dostępność na początkowym etapie planowania obiektu, co w niektórych przypadkach wpływać może nawet na obniżenie całkowitych wydatków poniesionych na jego budowę.

\section{Wnioski}

Kluczowym celem wszystkich omawianych w artykule strategii jest promowanie równości i zapewnienie pełnej dostępności do opieki zdrowotnej i uczestnictwa w życiu społecznym osobom z obniżoną funkcjonalnością, poprzez usuwanie istniejących barier w obiektach medycznych i zapobieganie powstawaniu nowych. Koncepcja uniwersalności zyskuje dużą popularność w dyskursie analitycznym, ponieważ wytycza nowe szlaki myślowe i jest oparta na idei egalitaryzmu społecznego w większym stopniu niż koncepcja ogólnej dostępności, bowiem „zasada uniwersalnego projektowania przewiduje, iż podstawowe działania i rozwiązania będą z założenia odpowiadały potrzebom wszystkich użytkowników" [10].

Bezkompromisowa implementacja wszystkich, w zasadzie słusznych, reguł projektowania uniwersalnego do praktyki projektowania szpitali nie zawsze jest jednak możliwa, nie zawsze jest konieczna i, co ważne, nie zawsze jest wskazana. Historia architektury XX wieku przypomina nam, że idee sprawiedliwości społecznej mają wielką moc sprawczą i wpływ na wyobraźnię ludzką, jednak czasem mogą okazać się nadmiernie dogmatyczne. Niezbędna jest natomiast otwartość i wszechstronna wiedza dotycząca potrzeb rożnych grup użytkowników szpitala, która pozwoli nam w przyszłości podejmować racjonalne i społecznie odpowiedzialne decyzje, uprawdopodobniające, że stopień autonomii każdego pacjenta będzie mógł stać się jego wyborem. Z dzisiejszej perspektywy 
wydaje się, że drogą do osiągniecia tego celu i poprawy obecnej, często katastrofalnej sytuacji, będą zarówno realizacje obiektów medycznych wierne idei projektowania uniwersalnego, jak i rozwiązania dedykowane osobom z niepełnosprawnościami, a jednocześnie bezpieczne i komfortowe dla wszystkich użytkowników, którzy w budynku szpitalnym stykają się bezpośrednio lub pośrednio z trudnymi i często nieoczekiwanymi sytuacjami. Podczas gdy w rozumieniu niniejszego artykułu priorytetem są potrzeby osób z długotrwałymi stanami występowania pewnych ograniczeń w funkcjonowaniu organizmu, z łatwiejszego dostępu do budynków służby zdrowia korzyści doświadczy każdy z nas na różnych etapach swojego życia. Z przeprowadzonych analiz wyłania się wniosek, że szpital może się stać nam bardziej przyjazny, pod warunkiem dokonania jego racjonalnego przystosowania na które składa się:

- spełnienie wymagań przepisów prawnych, których treść uzupełniona zostanie tymczasowo przez opracowywane w Polsce standardy dostępności, zawierające wykaz środków koniecznych do dokonania odpowiednich korekt w przestrzeni;

- perspektywiczne planowanie uwzględniające potrzeby obecnych i przyszłych użytkowników, w tym przede wszystkim osób z obniżoną sprawnością;

- stosowanie zarówno narzędzi o charakterze standardowym, jak i niekonwencjonalnych metod, w zależności od zastanego kontekstu, formy, funkcji i charakteru szpitala;

- dokonywanie regularnego audytu dostępności;

- prowadzenie konsultacji społecznych, w tym konsultacji z osobami z niepełnosprawnościami oraz organizacjami, którym umożliwia się przedstawienie własnych poglądów na temat racjonalnego dostosowania przestrzeni;

- zagwarantowanie wszystkim użytkownikom bezpieczeństwa, także w razie nagłych wypadków i pożaru, oraz właściwej i czytelnej informacji na temat sposobu korzystania z obiektu;

- zapewnienie środków o charakterze pomocniczym i, w przypadku ich braku, alternatywnych procedur korzystania z przestrzeni;

- uwzględnianie zasady racjonalnego dostosowania w planowaniu kosztów budowy i modernizacji szpitala.

Zarządcy budynku dostępnego powinni ponadto zapewniać odpowiednie szkolenia pracowników, motywować ich do rozwijania dodatkowych umiejętności służących komunikacji oraz gwarantować, że w trakcie użytkowania szpitala osoby zatrudnione rozumieją obowiązek dokonywania niezbędnych korekt w przestrzeni i posiadają zdolność do identyfikacji potencjalnych barier.

Od świadomości wszystkich osób zaangażowanych w projektowanie i organizację placówek zależy bowiem przyszłość polskiego budownictwa szpitalnego, na które w znacznej mierze składają się obiekty wzniesione w II połowie XX wieku, z myślą o zaspokojeniu najbardziej podstawowych potrzeb sanitarno-biologicznych anonimowego użytkownika o przeciętnych, uśrednionych potrzebach. Przekraczanie progu wytworzonych wówczas barier jest zadaniem wymagającym od projektantów cierpliwości, empatii, znajomości zarówno tymczasowych rozwiązań poprawiających jakość obiektów, jak i wiadomości z zakresu uniwersalnego projektowania. Szeroki zasób wiedzy osób odpowiedzialnych za kreowanie przestrzeni umożliwi bowiem nie tylko dokonywanie racjonalnych, choć czasem trudnych, wyborów, ale zwiększy także prawdopodobieństwo prawidłowego wdrażania reguł projektowania uniwersalnego, tam gdzie jest to możliwe i gdzie nie trzeba szukać kompromisów pomiędzy dotychczasowym sposobem użytkowania szpitala a uzasadnionymi potrzebami społecznymi.

\section{Literatura}

[1] Forty A. Words and Buildings. Thames and Hudson, London, 2000.

[2] Kuryłowicz E. Uniwersalność rozwiązań architektonicznych w kontekście otwierania środowiska wybudowanego dla wszystkich, jako wyraz i efekt postawy innowacyjnej - normalność w architekturze. Studia BAS 2/42 (2015) $203-217$.

[3] Kuryłowicz E. Projektowanie uniwersalne przestrzeni - doświadczenia polskie i międzynarodowe, perspektywy dla edukacji. Referat. Konferencja Projektowanie uniwersalne. Dostępność i uczestnictwo dla wszystkich, Warszawa, 2012.

[4] Rezolucja ONZ nr 61/06 z dnia 13 grudnia 2006: Konwencja Praw Osób Niepetnosprawnych (ang. Convention on the Rights of Persons with Disabilities). A/RES/61/106. 
[5] Wysocki M. i in. Realizacja zasady równości szans i niedyskryminacji, w tym dostępności dla osób z niepetnosprawnościami. Ministerstwo Rozwoju, Warszawa, 2015.

[6] Wysocki M. Budowa Miasta Przyjaznego na przykładzie Miasta Gdyni. Referat. Łódzki Konwent Regionalny II Kongresu Osób z Niepełnosprawnościami, Łódź, 2016.

[7] Stępień B. Standard dostępności dla Łodzi. Referat. Łódzki Konwent Regionalny II Kongresu Osób z Niepełnosprawnościami, Łódź, 2016.

[8] Easy Access to Historic Buildings. Historic England, London [https://www.visitengland.com/sites/default/files/historic_england_easy_access_to_historic_buildings_2015.pdf, dostęp: 04.05.2016].

[9] Truesdale S., Steinfeld E. Visit-ability an approach to Universal Design in housing. Rehabilitation Engineering Research Center on Universal Design at Buffalo, School of Architecture and Planning University at Buffalo The State University of New York, 2002.

[10] Projektowanie uniwersalne - Objaśnienie koncepcji, 2007. Ministerstwo Ochrony Środowiska Norwegia, Biuro Pełnomocnika Rządu ds. Osób Niepełnosprawnych, Ministerstwo Pracy i Polityki Społecznej, Warszawa [http://niepelnosprawni. gov.pl/container/publikacje/projektowanie-uniwersalne/projektowanie-uniwersalne.\%200bjasnienie\%20koncepcji. pdf, dostęp: 06.07.2016].

\title{
Universal design versus raising the level of accessibility of hospital facilities
}

\begin{abstract}
The contemporary architectural discourse puts an increasing emphasis on meeting the needs and expectations of persons with disabilities. Poland has been obliged to implement the regulations included in the Convention on the Rights of Persons with Disabilities in order to provide all the citizens with the highest standards and unlimited access to health care services. Thus it is necessary to answer the question of how to design buildings and medical services so that they follow the principles included in Art.25 of the Convention. Complex restructuring which covers the needs of all hospital users could become a crucial activity in developing a novel approach and setting new directions for the changes in the design and building of health care facilities.
\end{abstract}

Keywords: hospital architecture, accessibility, universal design 